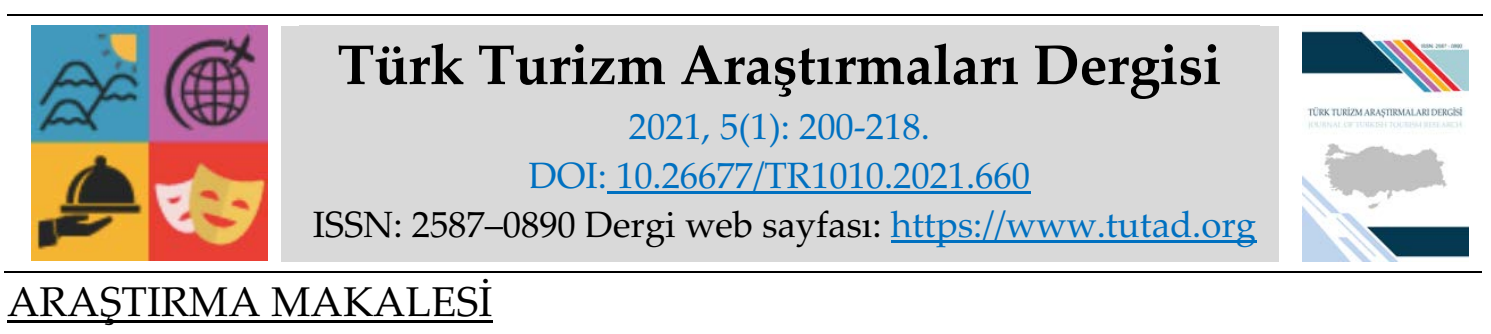

\title{
Bilinçli Farkındalık Felsefesinin Turizm Alanındaki Yeri: Çatalhöyük Örneği*
}

Dr. Mesut Murat ADABALI, Bağımsız Araştırmacı, e-posta: m.adabali@yahoo.com ORCID: https://orcid.org/0000-0001-6116-1236

Öz

Bireyin çevresinde gelişen olayları daha iyi bir şekilde yorumlayabilmesi ve yaptığ yorumlamalar sonucunda yaşadığı ortamı daha iyi anlamasını sağlayan bir düşünce yapısı olan bilinçli farkındalık, yaşamın her alanında uygulanabildiği gibi turizm alanında da hem bireysel gelişim için hem de turistik alanların geliştirilmesine yönelik kullanılabilmektedir. Çalışmanın amacı, Çatalhöyük Kültürel Miras Alanı'nı ziyaret eden yerli ve yabancı turistlerin bilinçli farkındalık düzeylerini ölçmektir. Çatalhöyük Neolitik Kenti'ni 2018 yılı Haziran-Kasım ayları arasında ziyaret eden 429 turistin bilinçli farkındalık düzeyleri ölçülmüştür. Elde edilen bulgular doğrultusunda adı geçen alanı ziyaret eden turistlerin bilinçli farkındalık düzeylerinin yüksek olduğu tespit edilmiştir. Ayrıca bilinçli farkındalık düzeyinin, bireylerin cinsiyetlerine ve uyruklarına göre değişim göstermediği fakat bireylerin medeni durumları, öğrenim düzeyleri ve yaşlarına göre değişim gösterdiği sonuçlarına ulaşılmıştır. Verilerin T-Testi ve ANOVA testi sonucunda ise turistler, Çatalhöyük'e yaptıkları ziyareti faydalı bulmamışlardır. Ayrıca gerçekleştirdikleri seyahatte eğlenmedikleri, yeni şeyler öğrenmedikleri ve keyif almadıkları gibi sonuçlara ulaşılmıştır. Bu duruma ek olarak, turistlerin tekrar Çatalhöyük'ü ziyaret etmek istemedikleri ve çevre koşullarından memnun olmadıkları elde edilen verilerin analizleri sonucunda ortaya çıkmaktadır.

* Çalışma yazarın 'Turizm Alanında Bilinçli Farkındalık, Destinasyon Deneyimi ve Fayda: İç Anadolu Bölgesi'nde Bulunan Kültürel Mirasları Ziyaret Eden Turistler Üzerinde Ampirik Bir Araştırma' başlıklı doktora çalışmasından üretilmiştir.

Anahtar Kelimeler: Çatalhöyük, Bilinçli Farkındalık, Turizm, Kültürel Miras, Turistik Destinasyonlar.

Makale Gönderme Tarihi: 28.10 .2020

Makale Kabul Tarihi: 06.03.20201

\section{Önerilen Atıf:}

Adabalı, M. M. (2021). Bilinçli Farkındalık Felsefesinin Turizm Alanındaki Yeri: Çatalhöyük Örneği, Türk Turizm Araştırmaları Dergisi, 5(1): 200-218.

(c) 2021 Türk Turizm Araştırmaları Dergisi. 


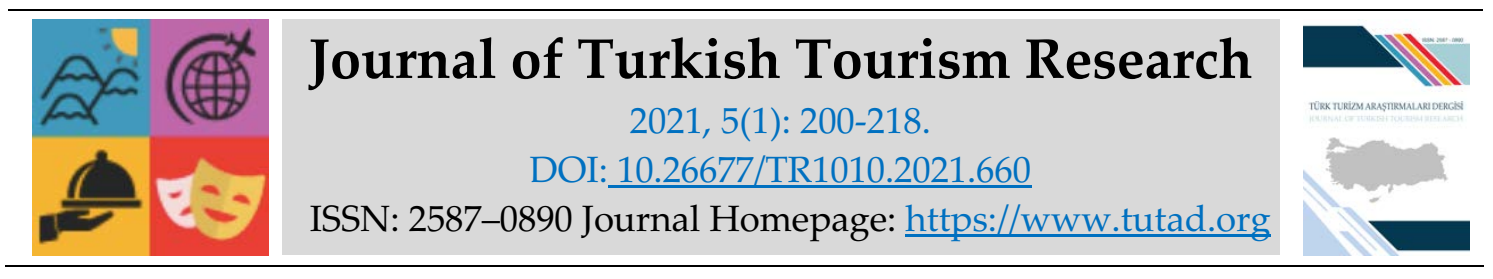

\title{
$\underline{\text { RESEARCH PAPER }}$
}

\section{Mindfulness Philosophy in Tourism: The Case of Çatalhöyük}

Dr. Mesut Murat ADABALI, Independent Researcher, e-mail: $\underline{\text { m.adabali@yahoo.com }}$ ORCID: https://orcid.org/0000-0001-6116-1236

\begin{abstract}
Mindfulness, which is a mindset that enables a better understanding of the environment can be applied in every area of life and individual development in the field of Tourism for both for the development of tourist areas can be used. The aim of this study, the tourists who prefer this type of tourism were measured in order to see mindfulness levels in the Çatalhöyük Neolitic City. In this study, from June to November 2018, 429 tourists' mindfulness levels measured who visited Çatalhöyük Neolithic City. According to the results, the level of mindfulness of tourists who visit the Çatalhöyük was high. Also, the level of individuals' mindfulness did not change according to gender and nationality, but changed according to the marital status, level of education and age of the individuals. As a result of the T-test and ANOVA test of the data, tourists did not find delightful their visit to Çatalhöyük. Besides, they did not have fun, did not learn new things and did not enjoy the journey which they perform. As a result, tourists do not want to visit Çatalhöyük again and they are did not satisfied with the environmental conditions.
\end{abstract}

Keywords: Çatalhöyük, Mindfulness, Tourism, Cultural Heritage, Touristic Destinations.

Received: 28.10 .2020

Accepted: 06.03.2021

\section{Suggested Citation:}

Adaball, M. M. (2021). Mindfulness Philosophy in Tourism: The Case of Çatalhöyük, Journal of Turkish Tourism Research, 5(1): 200-218.

(C) 2021 Türk Turizm Araştırmaları Dergisi. 


\section{GíRIŞ}

Bilinçli farkındalık (Mindfulness), turizm ile birlikte son yıllarda adı sıkça anılmaya başlayan, kökeni Budist inanışına dayanan ve bireyin geçmiş veya gelecek için endişe etmeden nasıl yaşayabileceğine rehberlik eden bir felsefedir. Nezaket, merak ve kabul hissi ile birlikte içsel ve dışsal deneyimlere dair bilincin gelişmesi (Alidina 2019: 12) olarak da tanımlanan bilinçli farkındalık aynı zamanda bireyin iç dünyasında ve çevresinde olup bitenlere eleştirisel gözle bakmadan, herhangi bir yargılamada bulunmadan gözlemleme yeteneğidir (Hayes vd., 2010: 239).

Bu çalışmanın amacı, Dünya tarihinde ilk yerleşik yaşamın kurulduğu alanlardan biri olan ve yapılan araştırmalara göre günümüzden yaklaşık 9.000 yıl önce kurulmuş bir kent olan Çatalhöyük Kültürel Miras Alanı'nı ziyaret eden yerli ve yabancı turistlerin bilinçli farkındalık düzeylerini ölçmektir. Demografik sonuçların da tartışıldığı bu çalışmaya 429 yerli ve yabancı turist katılmıştır. Bilinçli farkındalık düzeyinin ölçülmesinin sebebi, bilinçli farkındalık düzeyi yüksek olan birey, içerisinde bulunduğu durumu aktif bir şekilde sorgulayan, ilgili ve iyi yorumlama kabiliyeti olan bireydir ve bu birey, karşı karşıya kaldığı olaylar ile ilgili çok çabuk bir şekilde yeni bir bakış açısı geliştirebilmektedir.

Moscardo (1996) konu ile ilgili çalışmasında, bilinçli farkındalık felsefesinin küresel çapta destinasyonların yorumlanması üzerinde etkili olduğunu belirtmiştir. Frauman ve Norman (2004) ise bilinçli farkındalık uygulamalarının yapıldığı alanlarda turistlerin tatmin ve bilgi düzeylerinde artışın meydana geldiğini ifade etmiştir. Winkle ve Backman (2012) elde ettiği bulgular sonucunda turistik bir destinasyonu ziyaret eden turistlerin bilinçli farkındalık seviyeleri ile etkinlikten-ziyaretten duydukları memnuniyet arasında bir ilişki olduğu değerlendirmesi yapmıştır. Chen, Scott ve Benckendorff (2014) ise bilinçli farkındalık felsefesinin turizm sektörü üzerinde etkili olduğunu belirterek Ling, Noor ve Mustafa (2015)'nın ve Loureiro, Breazeal ve Radic (2019)'in çalışmalarında belirttiği gibi bilinçli farkındalık seviyesi bireylerde ne kadar yüksek ise, ziyaretten aldıkları zevkin o kadar yüksek olduğu sonucuna ulaşmıştır. Noor, Rasoolimanesh, Jaafaar ve Ganesan (2015) ve Taylor ve Norman (2019)'ın yaptığı çalışmalarda ise bireylerin bilinçli farkındalık seviyesinin destinasyon seçimine direkt etki ettiği belirtilmiştir. Türkçe literatürde ve Türkiye özelinde bu konu ile ilgili çalışmanın yapılmamış olması sebebiyle Çatalhöyük Neolitik Kenti'ni ziyaret eden turistlerden elde edilecek olan bilgilerin önemli olduğu düşünülmektedir.

Neolitik dönem, insanların avcılık ve toplayıcılık ile yaşamını sürdürdüğü, yerleşik hayata başladığı, yabani bitki tohumlarını toplayarak tarıma uğraştığı ve yabani hayvanları evcilleştirdiği dönemdir (Schmidt, 2007: 36). Çatalhöyük, coğrafi olarak Konya kapalı havzası olarak adlandırılan bölgede, Konya ilinin $52 \mathrm{~km}$. güneydoğusunda yer alan Çumra ilçesine bağlı Küçükköy mahallesinde yer almaktadır. Doğu ve batı höyük olarak isimlendirilen alanlardan oluşan Çatalhöyük 13,5 hektarlık bir alana yayılmıştır (Mellaart, 2003: 10). Kentin nüfusu en gelişmiş olduğu tarihte 8.000 'e kadar çıkmaktadır. Birbirine yakın ve sıkışık bir biçimde inşa edilmiş evlere girişler çatıdan yapılmaktadır. Evlerin duvarlarında avlanma sahnelerini yansıtan resimler ve geometrik şekiller bulunmaktadır (Yaylalı, 2010: 7).

Kısaca UNESCO (United Nations Educational, Scientific and Cultural Organization-Birleşmiş Milletler Eğitim, Bilim ve Kültür Kurumu) olarak bilinen kuruluş Dünya üzerinde bulunan kültürel mirasları korumak amacıyla belirli aralıklarla listeler yayınlamaktadır. Kültürel miras alanının listeye alınması için bazı kriterlerin olduğu bu listenin amacı, kültürel mirası koruma altına almanın yanı sıra adı geçen alanları tüm dünyaya tanıtmaktır. UNESCO, "Dünya Mirası ve Sürdürülebilir Turizm Programı" başlıklı çalışmasında, kültürel miras alanlarının bulunduğu turistik destinasyonlarda farkındalık oluşturarak, mevcutta bulunan kapasitelerini geliştirerek 
diğer paydaşlar ile birlikte sonuca varılmasını desteklemektedir. Ayrıca, "Dünya Miras Alanlarının Üstün Evrensel Değeri" konusunda kültürel miraslara sahip çıkmak ve yerel halkın da bu turizm hareketliliğine katılarak sürdürülebilir bir bağlantı oluşturmasını hedeflemektedir. Bu sebeple Çatalhöyük Neolitik Kenti 2012 yılından bu yana "Dünya Mirası Listesi” içerisinde yer almaktadır.

\section{KAVRAMSAL ÇERÇEVE}

Araştırma konusu ile ilgili bilinçli farkındalık, bilinçli farkındalık ve turizm kavramları aşağıda belirtilmiştir.

\section{BİLINÇLİ FARKINDALIK KAVRAMI}

Bilinçli farkındalık, bireyin geçmiş veya gelecek için endişe etmeden şimdiki zamanda keyifli bir biçimde nasıl yaşayabileceğini keşfetmesidir. Esasen kadim zamanlarda geliştirilmiş olup Doğu ve Batı kültürlerinde görülebilmektedir. Bilinçli farkındalığa sahip bireyler yaşam deneyimlerini daha olumlu bir duygusal tonla, daha objektif bir biçimde gözlemleyebilirler (Good vd., 2015: 117). Bilinçli farkındalık, bireyin kendi iç dünyasında gelişen olaylara eleştirisel gözle bakmadan, ön yargılı olmadan değerlendirme becerisidir (Hayes vd., 2010: 239). Bilinçli farkındalık, bireyin kendi sıkıntısıyla daha kolay başa çıkabilmesini sağlar ve empati duygusunu teşvik eder (Eisenberg vd., 1996: 199). Beitel, Ferrer ve Cecero (2005: 743)'nun çalışmasında da bilinçli farkındalığın empatik duygu ve endişe ile olumlu bir ilişkisi olduğu belirtilmiştir. Günlük aktivitelerde ve cinsel deneyimler sırasında bilinçli farkındalık, yetişkinler için bireysel, ilişkisel ve cinsel sonuçlarla bir dizi olumlu ilişki göstermektedir (Newcombe ve Weaver, 2016: 100). Bilinçli farkındalık aynı zamanda, zihinsel bir yetenek, zihinsel bir işlev olarak da tanımlanmaktadır. Bireyin hem etrafında gelişen olayları hem de gelişen bu olaylara karşı vermiş olduğu tepkiyi daha iyi gözden geçirmesini sağlar. Bu düşüncede, birey ikilem ile karşı karşıya kaldığında problemleri çözmekte ve sıkıntılarını gidermede farklı bir yaratıcılığa sahip olur (Steele, 2008: 14). Grossman, (2010: 89) ise bilinçli farkındalığın, bireyi gündelik yaşamındaki basit işlerden uzak tutan bir yol olduğu değerlendirmesinde bulunmaktadır. Bu yol duygusal, davranışsal, bilişsel, ahlaki, sosyal ve daha başka unsurları kapsamakta ve bireyin iyi oluşunu destekleyerek acı çekme halinin geçmesini sağlamaktadır.

Kara (2016: 31) araştırmasında, çeşitli araştırmacıların (Baer, Smith, Allen, 2004; Dekeyser, Raes, Leijssen, Leysen ve Dewulf, 2008) yayınlarından derlediği bilgilerle bilinçli farkındalığın dört temel beceri kazandırdığını belirtilmektedir. Bu becerilerin bireye kazandırılması için çeşitli bilinçli farkındalık programları geliştirilmiştir. Bunlar;

- Âna odaklanma: Birey, geçmişin geri gelmeyeceğini ve bu duruma müdahale edemeyeceğinin farkındadır. Bireyin geçmişi yeniden yaşama ve değiştirme gibi bir yeteneği yoktur. Gelecek ise henüz yaşanmadığ i için belirsizdir. Bu sebeple birey, içinde bulunduğu âna odaklanmalıdır.

- Mesafe koyma: Birey, yaşadığ duygulara ve düşüncelere yeniden ve daha objektif olarak bakma becerisi kazanmaktadır. Bu beceri aracılığı ile birey, kendisini düşüncenin bir parçası olarak görmez, düşünceyi sadece "düşünce" olarak görür ve bu sayede duygu ve düşüncelerine uzaktan bakabilme becerisi kazanır.

- Serbest bırakma: Birey, zihninde korku ve kaygı gibi olumsuz duygular aracılığı ile bir olay oluşturur ve bu düşünceler bir süre sonra bireyi esir almaya başlar. Bilinçli farkındalık felsefesinde birey bu olumsuz duygulara tepkisel yaklaşmak yerine bu olayları sakince karşılar ve olumsuz düşünceleri serbest bırakır. 
- Kabullenme: Birey, kendisini rahatsız eden duygu ve düşüncelerden kaçmak yerine bu deneyimleri tecrübe eder. Kabullenmede, yargılamaya yer yoktur, olaylara içtenlikle ve kibar yaklaşılmaktadır.

Klinik araştırmalar sonucunda kaygı ve ruh sağlığı kötüye giden bireylerde bilinçli farkındalık düzeyinin artırılması sonucunda yaşam kalitelerinde ve sağlıklarında iyileşme gözlemlenmiştir. Bir diğer araştırmada ise çalışma hayatında stresi aza indirme ve personelin bilinçli farkındalık düzeyini arttırmak amacıyla yapılan çalışma sonucunda personelin stresi azalmış ve psikolojik olarak kendilerini eskisine göre daha iyi hissettikleri belirtilmiştir (Laurie ve Blandford, 2016: 42).

\section{BİLINÇLİ FARKINDALIK ve TURİZM}

Bilinçli farkındalık ve turizm konusu ile ilgili ilk uygulama, Moscardo ve Pearce (1986) tarafından Birleşik Krallık'ta yapılmıştır. Ziyaretçilerin kültürel miras alanını nasıl yorumladığı ve sunulan hizmet kalitesinin hangi düzeyde olduğun anlamak için yapılan uygulamada, bilinçli farkındalık düzeyi yüksek olan turistlerin daha fazla öğrenme ve daha fazla memnuniyet düzeyine sahip olduğu tespit edilmiştir (Moscardo, 2009: 186). Bilinçli farkındalık düzeyinin ölçülmesinin sebebi, bu farkındalığa sahip olan bireylerin seyahatleri esnasında çevresini daha iyi yorumlaması ve bilgi edinmeye daha yatkın olması olarak düşünülmektedir (Moscardo, 1996: 380). Aynı zamanda yüksek bilinçli farkındalık düzeyine sahip olan bireylerin seyahatlerinden elde ettikleri deneyimi diğer bireylerle paylaşma eğiliminde oldukları da düşünülmektedir (Moscardo, 2009: 186). Bilinçli farkındalık sahibi turistlerin, diğer turistlere göre kültürel mirasları daha iyi değerlendirdikleri ve anladıkları belirtilmektedir. Bilinçli farkındalığın aynı zamanda turistlerin deneyim kalitesini arttırdığı ve turistler ile miras alanları arasında sürdürülebilir bir bağlantı oluşturduğu şeklinde de yorumlanmaktadır (Chen vd., 2014: 2). Bilinçli farkındalık düzeyi yüksek turistler, bilgileri aktif olarak işleyen ve destinasyonda bulunan etkinlikleri sorgulayan ve sonuç olarak kültürel mirası ve çevresini daha iyi değerlendirebilen turistlerdir (Prentice, Guerin ve McGugan, 1998: 7). Frauman ve Norman (2004)'ın çalışmasında ise bilinçli farkındalığın yapısı ve doğal, kültürel veya tarihsel temelli turizm destinasyonlarına gelen ziyaretçilere, bilinçli farkındalık uygulamalarının yapıldığı ve bu alanlarda turistlerin tatmin, bilgi ve farkındalık düzeylerinin artış eğiliminde olduğu belirlenmiştir. Ghaderi ve Som (2013) ise çalışmalarında, turizm işletmelerinde meydana gelen krizlerin çözümünde bilinçli farkındalık uygulamalarının nasıl kullanılabileceği ve kullanım şekillerinden bahsedilmiştir. Turizm işletmelerinde görev yapan personellere de bilinçli farkındalıklarını geliştirmeleri için eğitim verilmesi tavsiye edilmiştir. Dutt ve Ninov (2016) turizm işletmelerinin bilinçli farkındalık ile ilgili görüşlerini almak amacıyla yaptığı bu çalışmada, bilinçli farkındalık felsefesini kavramış olmanın, işletmeler açısından hizmet kalitelerini artırma konusunda önemli bir unsur olduğu ve bireyler açısından da öğrenme, ziyaret edilen destinasyonu tekrar ziyaret etme isteği konusunda oldukça öneme sahip bir durum olduğu belirtilmektedir. Taylor ve Norman (2019) ise bilinçli farkındalık felsefesinin seyahat motivasyonu üzerinde etkisinin olduğu ve bu sayede turistlerin kendilerine en uygun destinasyonu seçtikleri belirtilmiştir. Ayrıca bu turistlerin yapmış oldukları seyahatten memnun oldukları varsayılmış ve elde edilen verilerin analizi sonucunda bu varsayımlar doğrulanmıştır. Tan, Noor, Rasoolimanesh ve Mustafa (2020: 27) kültürel miras alanlarındaki ziyaretçi deneyiminin tasarımında açılayıcı bilgiler, birden fazla duyuya hitap eden medya ögeleri ve görselleştirmeler dahil edilerek ziyaretçilerin bilinçli farkındalık düzeylerinin geliştirilebileceğini belirtmektedir. Stankov Filimonau ve Vujicic (2020: 709) 2020 yılında tüm dünyayı etkisi altına alan Covid-19 pandemisi ile birlikte bilinçli farkındalık düzeyi daha yüksek bireylerin turistik hareketlerde bulunabileceğine ve bunun sonucunda sürdürülebilir turist deneyimlerine yol açabileceğini belirtmişlerdir. 
Araştırmanın temel amacı doğrultusunda yukarıda belirtilen alt amaçlar ve kavramsal model dikkate alınarak araştırmaya ilişkin geliştirilen hipotezler aşağıda sıralanmıştır.

Hipotez 1: Ziyaretçilerin cinsiyetlerine göre bilinçli farkındalık düzeyleri farklılık göstermektedir. Hipotez 2: Yabancı ziyaretçilerin bilinçli farkındalık düzeyleri yerli ziyaretçilere göre daha yüksektir.

Hipotez 3: Bilinçli farkındalık düzeyi, katılımcıların evli ya da bekâr olma durumlarına göre farklılık göstermektedir.

Hipotez 4: Bilinçli farkındalık düzeyi, katılımcıların yaş gruplarına göre anlamlı farklılık göstermektedir.

Hipotez 5: Bilinçli Farkındalık düzeyi, öğrenim düzeyi arttıkça farklılık göstermektedir.

\section{YÖNTEM}

$\mathrm{Bu}$ araştırmada hem birincil hem de ikincil verilerden yararlanılmıştır. İkincil veriler, birinci verilerin elde edilmesi için yapılacak olan çalışmalardır ve elde edilecek bulguların daha iyi anlaşılması için gerekli ve önemlidir. İkincil verilerin elde edilmesinde konu ile ilgili Türkçe ve İngilizce dillerinde daha önceden yapılmış yüksek lisans ve doktora tezleri, üniversitelerin kullanımına açı olan uluslararası veri tabanlarından elde edilen akademik çalışmalar, konu ile ilgili süreli ve süresiz yayınlar ve araştırma konusu ile ilgili güncel bilgilere ulaşabilmek için resmi kurum ve kuruluşların internet siteleri kullanılmıştır. Veriler anket formu aracıllı̆g ile elde edilmiştir. Anket tekniği, araştırma alanında elde edilmek istenen verilerin somut ve rakamsal sonuçlarının belirlenmesi için önemli bir veri toplama tekniği olarak kabul görmektedir (Kağıtçıbaşı, 2004: 55). Bu araştırmada, Çatalhöyük Kültürel Miras Alanı'nı ziyaret eden yerli ve yabancı turistlerin ziyaretlerinin hemen sonrasinda kendilerine yöneltilen anket formunu cevaplaması istenmesinin sebebi araştırmanın hedef kitlesine daha etkin bir biçimde ulaşılmak istenmesidir. Katılımcılardan elde edilen geri bildirimlere göre, özellikle küçük gruplar halinde gelen misafirler, anket formu sunulduktan sonra gerçekleştirdikleri ziyareti hem kendi kendilerine hem de grup içerisinde tekrar değerlendirerek gözden kaçırdıkları veya kültürel miras alanı ile ilgili farkında olmadıkları önemli bilgileri de bu şekilde öğrenme fırsatı buldukları düşünülmektedir.

Anket içeriği, ilgili literatürde yapılan incelemeler sonucunda daha önceden kullanılan, geçerliliği güvenirliliği kanıtlanmış ölçeklerin değerlendirilmesiyle gerçekleştirilmiştir. Alt boyutları "Farkındalık", "Temel Bilinçli Farkındalık" ve "Meraklılık ve Dikkat" olan "Bilinçli Farkındalık Ölçeği ( $\alpha=0.91$, V.E.=\%70)" (Frauman ve Norman, 2004) bireylerin bilinçli farkındalık düzeylerini ölçmek için kullanılmıştır. On beş maddeden oluşan ölçek tek bir toplam puan üzerinden değerlendirilmektedir. Yüksek puanlar bilinçli farkındalığın yüksek olduğu anlamına gelmektedir. Bu ölçek, günlük yaşamdaki anlık deneyimlerin farkında ve bunlara karşı dikkatli olma yönündeki genel eğilimi ölçen bir ölçektir. Alt boyutları "Öğrenme", "Keyif Alma" ve "Kaçış" olan "Fayda Ölçeği ( $\alpha=0.92$ V.E.= \%49,9)" (Manfredo, Tarrant ve Driver, 1996) ve alt boyutlar "Destinasyon Tecrübesi" ve "Kontrol" olan "Destinasyon Seçimi Ölçeği ( $\alpha=0.94$, V.E.= \%44)" (Sparks, 2007) ana bölümlerinden oluşmaktadır. Çalışma sürecinin sonunda anket formunda yer alacak maddelerin neler olacağı kararlaştırılmıştır. Bu bağlamda anket formu, katılımcıların oranının düşmemesi için uzman görüşleri dikkate alınarak tasarlanmıştır. Anket formunun oluşturulmasında adı geçen ölçeklere ek olarak demografik bilgileri elde etmeye yönelik soruların olduğu anket formu üç farklı dilde (Türkçe, İngilizce, Japonca) 1 sayfa olarak hazırlanmıştır ve 44 adet sorudan oluşmaktadır. Örneklem seçiminde asıl olan, örneklemin, alındığı evreni temsil etmesidir. Bu durumda ne kadar, hangi büyüklükte bir örneklemin evrenini temsil edebileceği konusu önem kazanmaktadır. Örneklem büyüklüğünde evrenin 
büyüklügü ve kendisine göre örneklem alınan değişkene göre evrenin heterojenlik derecesi etkili olur. Temel kural evren ne denli büyükse örneklemin de o denli büyük olmasıdır (Balcı, 2004: 91). Katılımcılar, destinasyonları ziyaret eden yerli ve yabancı turistler arasından tesadüfi örneklem yöntemi ile seçilmiştir. Toplamda 600 anket formu katılımcılara dağıtılmış, bunların 429'u geçerli olarak değerlendirilmiştir. Anket uygulaması 2018 yılı Haziran-Kasım ayları arasında gerçekleştirilmiştir.

Tablo 1. Örneklem Hata Payına Göre Alınabilecek Örneklem Büyüklüğü

\begin{tabular}{|c|c|c|c|c|c|c|c|c|c|}
\hline \multirow{2}{*}{$\begin{array}{l}\text { Evren } \\
\text { Büyüklüğg̈ü }\end{array}$} & \multicolumn{3}{|c|}{$\begin{array}{l}+\quad 0.03 \text { örnekleme } \\
\text { hatas1 (d) }\end{array}$} & \multicolumn{3}{|c|}{$\begin{array}{l}+-0.05 \text { örnekleme hatası } \\
\text { (d) }\end{array}$} & \multicolumn{3}{|c|}{$\begin{array}{l}+-0.10 \text { örnekleme hatası } \\
\text { (d) }\end{array}$} \\
\hline & $\begin{array}{l}\mathrm{p}=0.5 \\
\mathrm{q}=0.5 \\
\text { (heterojen) }\end{array}$ & $\begin{array}{l}\mathrm{p}=0.8 \\
\mathrm{q}=0.2\end{array}$ & $\begin{array}{l}\mathrm{p}=0.3 \\
\mathrm{q}=0.7\end{array}$ & $\begin{array}{l}\mathrm{p}=0.5 \\
\mathrm{q}=0.5 \\
\text { (heterojen) }\end{array}$ & $\begin{array}{l}\mathrm{p}=0.8 \\
\mathrm{q}=0.2\end{array}$ & $\begin{array}{l}\mathrm{p}=0.3 \\
\mathrm{q}=0.7\end{array}$ & $\begin{array}{l}\mathrm{p}=0.5 \\
\mathrm{q}=0.5 \\
\text { (heterojen) }\end{array}$ & $\begin{array}{l}\mathrm{p}=0.8 \\
\mathrm{q}=0.2\end{array}$ & $\begin{array}{l}\mathrm{p}=0.3 \\
\mathrm{q}=0.7\end{array}$ \\
\hline 100 & 92 & 87 & 90 & 80 & 71 & 77 & 49 & 38 & 45 \\
\hline 500 & 341 & 289 & 321 & 217 & 165 & 196 & 81 & 55 & 70 \\
\hline 750 & 441 & 358 & 409 & 254 & 185 & 226 & 85 & 57 & 73 \\
\hline 1.000 & 516 & 406 & 473 & 278 & 198 & 244 & 88 & 58 & 75 \\
\hline 2.500 & 748 & 537 & 660 & 333 & 224 & 286 & 93 & 60 & 78 \\
\hline 5.000 & 880 & 601 & 760 & 357 & 234 & 303 & 94 & 61 & 79 \\
\hline 10.000 & 964 & 639 & 823 & 370 & 240 & 313 & 95 & 61 & 80 \\
\hline 25.000 & 1023 & 665 & 865 & 378 & 244 & 319 & 96 & 61 & 80 \\
\hline 50.000 & 1045 & 674 & 881 & 381 & 245 & 321 & 96 & 61 & 80 \\
\hline 100.000 & 1056 & 678 & 888 & 383 & 245 & 321 & 96 & 61 & 81 \\
\hline 1.000 .000 & 1066 & 682 & 896 & 384 & 246 & 323 & 96 & 61 & 81 \\
\hline 100 Milyon & 1067 & 683 & 896 & 384 & 245 & 323 & 96 & 61 & 81 \\
\hline
\end{tabular}

Kaynak: Yazıcıoğlu ve Erdoğan, 2004: 45, p=gerçekleşme olasılığı, q=gerçekleşmeme olasılığ1

Tablo 1.'de ortalama örneklem büyüklüklerinde doğru kestirim olasılıkları gösterilmektedir. Kestirimdeki tamlığın asıl belirleyicisi örneklemin evrene oranı olmayıp, gerçek örneklem büyüklügüüür. Genelde 150 ya da 200'e kadar olan örneklem artışlarında kestirimde istenen tamlığa ulaşılabilir. Farklı büyüklükteki evrenler için kurumsal örneklem büyüklükleri ve \%95 keskinlik düzeyi ile tolerans gösterilebilir (Balcı, 2004: 91). Araştırmanın ana kütlesini adı geçen kültürel mirasları 2018 yılında ziyaret eden turistlerin toplam sayısı oluşturmaktadır (4.725 kişi). Tablo 2.'ye göre örneklemin yeterli görülmesi için ulaşılması gereken sayı 384 olarak belirtilmiştir ve araştırmaya konu olan katılımcıların sayısı 429'dur. Bu sonuçlara göre katılımcıların sayısı, örneklemin temsil edilmesi için yeterli temsil gücüne sahiptir.

Tablo 2. Yıllara Göre Ziyaretçi Sayıları

\begin{tabular}{|l|c|}
\hline Y11 & Çatalhöyük Ören Yeri \\
\hline $\mathbf{2 0 1 4}$ & 17.992 \\
\hline $\mathbf{2 0 1 5}$ & 8.188 \\
\hline $\mathbf{2 0 1 6}$ & 13.127 \\
\hline $\mathbf{2 0 1 7}$ & 4.595 \\
\hline $\mathbf{2 0 1 8}$ & 4.725 \\
\hline Toplam & $\mathbf{4 8 . 6 2 7}$ \\
\hline
\end{tabular}

Kaynak: Döner Sermaye İşletmesi Merkez Müdürlüğü (DÖSIMM) 
Elde edilen verilen bilgisayar ortamına aktarılmasında sonra istatistiksel analizlerin yapılabilmesi için paket programlar kullanılmıştır. Veri girişi tamamlandıktan sonra verilerin analizinde kullanılacak olan istatistiksel testler belirlenmiştir. Buna göre araştırmada betimleyici istatistiklerden, frekans analizi ve fark analizlerinden yararlanılmıştır.

\section{AÇIMLAYICI FAKTÖR ANALIZİ}

Faktör analizinden önce değişkenler arasındaki karşılıklı korelasyon düzeyi ve faktör analizine uygunluğu Kaiser-Meyer-Olkin (KMO) testiyle değerlendirilmiştir (Bülbül, 2003: 220). Bu test sonucunda elde edilen sonuçlar Tablo 3.'te görülmektedir.

Tablo 3. Ölçeklerin Kaiser Meyer Olkin (KMO) Değerleri

\begin{tabular}{|l|c|c|c|}
\hline Ölçekler & KMO & Bartlett & $\mathbf{p}$ \\
\hline Bilinçli Farkındalık Ölçeği & 0,91 & 517,02 & $\mathbf{0 , 0 0}$ \\
\hline Fayda Ölçeği & 0,85 & 293,20 & $\mathbf{0 , 0 0}$ \\
\hline Destinasyon Seçimi Ölçeği & 0,91 & 341,24 & $\mathbf{0 , 0 0}$ \\
\hline
\end{tabular}

KMO'da 0,50'den düşük değerler kabul edilemez düzeyi ifade ederken, 0,90 düzeyindeki değerler çok iyi olarak kabul edilmektedir (Sharma, 1996: 116). Tablo 3.'te görüldüğü üzere KMO değerlerinin ikisi (Bilinçli Farkındalık ve Destinasyon Seçimi) çok iyi olarak kabul edilen 0,90 değerinden yüksektir. Diğer ölçeğin puanı (Fayda Ölçeği) ise iyi olarak kabul edilen değerler arasındadır. Faktör analizi yapılmadan önce bu değerlere göz atmak gerekir çünkü bu değerlerin yüksek veya düşük olma durumu faktör analizi yapılmasına karar vermeyi sağlamaktadır. Değişkenler arasında var olan ilişkinin analiz yapılabilmesi için uygunluk değerlerine göz atmak gerekir. Bu noktada Bartlett testinin sonuçlarına bakılmalıdır. KMO ve Bartlett testlerinin sonucunda bu çalışmada kullanılan ölçeklerin faktör analizi için uygun olduğu görülmektedir.

Açımlayıcı faktör analizi, gözlenen değişkenler ile bilinmeyen gizil değişkenler arasındaki bağlantıyı göstermektedir. Bu analizde ölçek maddelerinin ilgili faktörler altında gözükmesi ve yüksek bir faktör yükü puanına sahip olması beklenmektedir (Çokluk, Şekercioğlu ve Büyüköztürk, 2012: 189). Bu çalışmada araştırma modelini yapısal analiz ile incelemeden önce açılayıcı faktör analizi ile modeldeki değişkenlerin boyutluluğu araştırılmış ve boyutların içsel güvenilirliklerine bakılmıştır. Analizde, özdeğerleri 1'den büyük olan faktörler dikkate alınmış, faktör yüklerinin 0,50 'den büyük olması ve Cronbach's Alfa değerlerinin 0,70'e eşit veya büyük olması şartı aranmıştır. Tablo 4.'te her bir boyuta ilişkin Cronbach's Alfa değeri, özdeğer, açılanan varyans ve maddelere ait faktör yükleri yer almaktadır.

Açımlayıcı faktör analizi sonucunda, bilinçli farkındalık ölçeği üç alt boyuttan oluşmaktadır (farkındalık, merak ve dikkat, temel bilinçli farkındalık) ve bu boyutların da üç faktöre yüklendiği görülmektedir. Fayda ölçeği de benzer şekilde üç alt boyuttan oluşmaktadır (öğrenme, keyif, kaçış) ve bu boyutların da üç faktöre yüklendiği görülmektedir. Destinasyon seçimi ölçeği ise iki alt boyuttan oluşmaktadır (destinasyon tecrübesi, kaçış) ve bu boyutların da iki faktöre yüklendiği görülmektedir. Ölçeklerin tamamının özdeğerlerinin 1'den büyük ve faktör yüklerinin 0,50'ten büyük olduğu görülmektedir. Bu sonuçlar anket formunda yer alan ölçeklerin iyi bir yapısal geçerliliğe sahip olduğunu göstermektedir. Ayrıca Cronbach's Alfa katsayılarının da 0,70'den büyük olması ölçeklerin içsel tutarlılığa sahip olduğunu ifade etmektedir. Bu sonuçlar ölçülmek istenen özelliğin büyük olasılıkla doğru olarak ölçüldüğünü göstermektedir ve ölçeklerin yapısal geçerlilikleri sağlanmıştır. 
Tablo 4. Ölçeklerin Açımlayıcı Faktör Analizi Sonuçları (F=Faktör, TAV= Toplam Açıklanan Varyans)






\section{BULGULAR}

Tablo 5'te görüldüğü gibi betimleyici istatistikler sonucunda katılımcıların bilinçli farkındalık düzeyi yüksektir. Bilinçli farkındalık ölçeğinin puan ortalaması alınarak soru sayısına bölünmüştür ve hesaplama sonucunda aritmetik ortalamanın " 3 "ten yüksek olduğu tespit edilmiştir. Bu sebeple Çatalhöyük Kültürel Miras Alanı'nı ziyaret eden turistlerin bilinçli farkındalık düzeyi yüksek denilebilir. Bu bulgular Dutt ve Ninov (2016)'un bulgularını desteklemektedir. Bilinçli farkındalık düzeyi yüksek olan turistlerin diğer turistlere göre gerçekleştirdikleri seyahati daha iyi değerlendirdikleri ve anladıkları yapılan araştırmalarda belirtilmiştir (Ling vd., 2015; Dutt ve Ninov, 2015; Moscardo, 2009). Yüksek bilinçli farkındalık düzeyi, turistlerin deneyim kalitesini arttırmakta ve turistler ile miras alanları arasında sürdürülebilir bir bağlantı oluşturmaktadır.

Tablo 2. Katılımcıların Bilinçli Farkındalık Düzeyleri

\begin{tabular}{|l|c|c|c|}
\hline Ölçek & Ortalama (Mean) & İfade Sayısı & Aritmetik Ortalama (X) \\
\hline Bilinçli Farkındalık & 65,45 & 17 & 3,85 \\
\hline
\end{tabular}

\section{DEMOGRAFIK ÖZELLIKLERE İLIŞKİN SONUÇLAR}

Araştırmada demografik uyruk, yaş, cinsiyet, medeni durum ve öğrenim durumu temsil etmektedir. Katılımcların demografik özellikleri, frekans ve yüzdeleri Tablo 6.'da verilmiştir.

Tablo 6. Demografik Değişkenler

\begin{tabular}{|c|c|c|c|}
\hline $\begin{array}{l}\text { Demografik } \\
\text { Değişkenler }\end{array}$ & Değer & $\mathbf{n}$ & Yüzde \\
\hline \multirow{3}{*}{ Uyruk } & Türk & 208 & 48,5 \\
\hline & Yabanc1 & 221 & 51,5 \\
\hline & Toplam & 429 & 100 \\
\hline \multirow{5}{*}{ Yaş } & 24 Yaş ve Altı & 91 & 21,2 \\
\hline & $25-34$ & 149 & 34,7 \\
\hline & $35-44$ & 121 & 28,2 \\
\hline & 45 Yaş ve Üstü & 68 & 15,9 \\
\hline & Toplam & 429 & 100 \\
\hline \multirow{3}{*}{ Cinsiyet } & Kadın & 161 & 37,5 \\
\hline & Erkek & 268 & 62,5 \\
\hline & Toplam & 429 & 100 \\
\hline \multirow{3}{*}{ Medeni Durum } & Evli & 184 & 42,9 \\
\hline & Bekâr & 245 & 57,1 \\
\hline & Toplam & 429 & 100 \\
\hline \multirow{6}{*}{ Öğrenim Durumu } & İlköğretim & 27 & 6,3 \\
\hline & Lise & 46 & 10,7 \\
\hline & Önlisans & 51 & 11,9 \\
\hline & Lisans & 159 & 37,1 \\
\hline & Lisansüstü & 146 & 34,0 \\
\hline & Toplam & 429 & 100 \\
\hline
\end{tabular}


Anket uygulamasına $208(\% 48,5)$ Türk, 221 (\%51,5) Yabancı turist katılmıştır. Katılımcıların \%21,2'si (91 kişi) 24 yaş ve altındadır. 25-34 yaş aralığı \%34,7 (149 kişi), 35-44 yaş aralığı \%28,2 (121 kişi), 45 yaş ve üstü \%15,9 (68 kişi) olarak temsil edilmektedir. Cinsiyetleri incelendiğinde ise \%37,5 'ini (161 kişi) kadın katılımcılar, \%62,5'ini (268 kişi) ise erkek katılımcılar oluşturmaktadır ve \%42,9'u (184 kişi) evli, \%57,1'i (245 kişi) ise bekârdır. Ankete katılanların \%6,3'ü (27 kişi) ilköğretim, \%10,'si (46 kişi) lise, \%11,9'u (51 kişi) önlisans, \%37,1'i (159 kişi) lisans ve \%34,0’ü (146 kişi) lisansüstü mezunudur.

\section{FARK TESTLERI}

Fark testleri öncesinde elde edilen verilerin normal dağılıp dağılmadığını öğrenmek için normallik testine başvurulmuştur. Test sonucunda verilerin normal dağılım gösterdiği sonucuna varılmıştır çünkü Gravetter ve Wallnau (2013: 210)'ya göre normallik testi sonucunda Skewness ve Kurtosis değerleri -1.96 ile +1.96 arasında dağılım gösteriyor ise elde edilen verilerin normal dağılım gösterdiği belirtilmektedir. Bu sebeple araştırmada bağımsız iki grup için $\mathrm{T}$ testi, bağımsız ikiden fazla grup için ANOVA testi kullanılmıştır.

Tablo 7. Normallik Testi Sonuçları

\begin{tabular}{|l|c|c|}
\hline \multirow{2}{*}{ Ölçek } & \multicolumn{2}{|c|}{ Normallik Testi Sonuçları } \\
\hline Bilinçli Farkındalık & Skewness & Kurtosis \\
\hline Fayda & $-1,21$ & 0,63 \\
\hline Destinasyon Deneyimi & $-0,42$ & $-0,81$ \\
\hline
\end{tabular}

Hipotez 1: Ziyaretçilerin cinsiyetlerine göre bilinçli farkındalık düzeyleri farklllı göstermektedir. Dutt ve Ninov'un (2016) araştırmasında, bilinçli farkındalık düzeyi ile anket uygulamasına katılan turistlerin cinsiyetleri arasında anlamlı farklılık olduğunu belirtmiştir. Bu araştırmada ise elde edilen verilere $\mathrm{T}$-testi uygulanması sonucunda cinsiyetler arasında anlamlı farklılık bulunamamıştır, hipotez reddedilmiştir $(\mathrm{p}=0,85)$. Bilinçli farkındalık, Fayda ve Destinasyon Deneyimi ölçeklerine ait test sonuçları Tablo 8.'de görülmektedir.

Tablo 3. Katılımcıların Bilinçli Farkındalık Puanı Ortalamalarının Cinsiyete Göre Karşılaştırılması

\begin{tabular}{|c|c|c|c|c|c|c|}
\hline Ölçek & Cinsiyet & $\mathbf{n}$ & Ort. & SS & $\mathbf{t}$ & p \\
\hline \multirow{2}{*}{$\begin{array}{l}\text { Bilinçli } \\
\text { Farkındalık }\end{array}$} & Kadın & 161 & 3,85 & 0,75 & \multirow{2}{*}{0,16} & \multirow{2}{*}{0,85} \\
\hline & Erkek & 268 & 3,84 & 0,75 & & \\
\hline \multirow{2}{*}{ Fayda } & Kadın & 161 & 3,49 & 0,85 & \multirow{2}{*}{$-0,19$} & \multirow{2}{*}{0,30} \\
\hline & Erkek & 268 & 3,51 & 0,81 & & \\
\hline \multirow{2}{*}{$\begin{array}{l}\text { Destinasyon } \\
\text { Deneyimi }\end{array}$} & Kadın & 161 & 3,02 & 1,06 & \multirow{2}{*}{0,58} & \multirow{2}{*}{0,20} \\
\hline & Erkek & 268 & 2,95 & 1,08 & & \\
\hline
\end{tabular}


Hipotez 2: Yabancı ziyaretçilerin bilinçli farkındalık düzeyleri yerli ziyaretçilere göre daha yüksektir. Elde edilen verilere uygulanan T-testi sonucunda yerli ve yabancı turistler arasında bilinçli farkındalık düzeyi ile ilgili anlamlı farklılık bulunamamıştır, hipotez reddedilmiştir $(\mathrm{p}=0,88)$. Fayda ve Destinasyon Deneyimi ölçeklerine bakıldığında da anlamlı bir farklılık olmadığı görülmektedir. Bu konuya ilişkin veriler Tablo 9.'da görülmektedir.

Tablo 4. Katılımcıların Bilinçli Farkındalık Puanı Ortalamalarının Yerli-Yabancı Ziyaretçiye Göre Karşılaştırılması

\begin{tabular}{|c|c|c|c|c|c|c|}
\hline Ölçek & Uyruk & $\mathrm{n}$ & Ort. & SS & $t$ & $p$ \\
\hline \multirow{2}{*}{$\begin{array}{l}\text { Bilinçli } \\
\text { Farkındalık }\end{array}$} & Yerli & 208 & 3,82 & 0,76 & \multirow{2}{*}{$-0,62$} & \multirow{2}{*}{0,88} \\
\hline & Yabancı & 221 & 3,87 & 0,74 & & \\
\hline \multirow{2}{*}{ Fayda } & Yerli & 208 & 3,68 & 0,78 & \multirow{2}{*}{4,59} & \multirow{2}{*}{0,06} \\
\hline & Yabanc1 & 221 & 3,33 & 0,83 & & \\
\hline \multirow{2}{*}{$\begin{array}{l}\text { Destinasyon } \\
\text { Deneyimi }\end{array}$} & Yerli & 208 & 3,34 & 0,97 & \multirow{2}{*}{7,03} & \multirow{2}{*}{0,08} \\
\hline & Yabancı & 221 & 2,64 & 1,06 & & \\
\hline
\end{tabular}

Hipotez 3: Bilinçli farkındalık düzeyi, katılımclların evli ya da bekâr olma durumlarına göre farklılık göstermektedir. Elde edilen verilere uygulanan T-Testi sonuçlarına göre, evli ve bekâr turistler arasında bilinçli farkındalık düzeyi ile ilgili anlamlı farklılık olduğu tespit edilmiştir ve hipotez kabul edilmiştir $(\mathrm{p}=0,03)$. Buna göre evli turistler $(3,98)$ bekâr turistlere $(3,46)$ göre daha yüksek düzeyde bilinçli farkındalığa sahiptir. Konuya ilişkin diğer veriler Tablo 10.'da gösterilmiştir.

Tablo 5. Katılımcıların Bilinçli Farkındalık Puanı Ortalamalarının Medeni Durumlarına Göre Karşılaştırılması

\begin{tabular}{|c|c|c|c|c|c|c|}
\hline Ölçek & $\begin{array}{l}\text { Medeni } \\
\text { Durum }\end{array}$ & $\mathbf{n}$ & Ort. & SS & t değeri & $\mathrm{p}$ \\
\hline \multirow{2}{*}{$\begin{array}{l}\text { Bilinçli } \\
\text { Farkındalık } \\
\text { (Toplam) }\end{array}$} & Evli & 184 & 3,98 & 3,90 & \multirow{2}{*}{1,16} & \multirow{2}{*}{0,03} \\
\hline & Bekâr & 245 & 3,46 & 3,81 & & \\
\hline \multirow{2}{*}{ Fayda (Toplam) } & Evli & 184 & 3,21 & 3,60 & \multirow{2}{*}{2,11} & \multirow{2}{*}{0,74} \\
\hline & Bekâr & 245 & 3,44 & 3,43 & & \\
\hline \multirow{2}{*}{$\begin{array}{l}\text { Destinasyon } \\
\text { Deneyimi } \\
\text { (Toplam) }\end{array}$} & Evli & 184 & 3,56 & 3,11 & \multirow{2}{*}{2,27} & \multirow{2}{*}{0,10} \\
\hline & Bekâr & 245 & 3,71 & 2,88 & & \\
\hline
\end{tabular}

Hipotez 4: Bilinçli Farkındalık düzeyi, öğrenim düzeyi arttıkça farklılık göstermektedir. Ölçeklerin puanları arasında var olan farklılıkları ortaya koymak için yapılan ANOVA testinde, "p değeri< $<.05$ " olduğunda, istatistiksel olarak anlamlı olduğu kabul edilmektedir. Dutt ve Ninov'un (2016) araştırmasında, bilinçli farkındalık düzeyi ile turistlerin öğrenim düzeyi arasında anlamlı bir farklılık bulunamamıştır. Bu araştırma için elde edilen verilerin ANOVA testi ile analizi sonucunda turistlerin öğrenim düzeyleri ile bilinçli farkındalık düzeyleri arasında anlamlı farklılık bulunmaktadır ve hipotez kabul edilmiştir $(\mathrm{p}=0,00)$. Konuya ilişkin veriler Tablo 11.'de görülmektedir. 
Tablo 11. Katılımcıların Bilinçli Farkındalık Puanı Ortalamalarının Öğrenim Düzeylerine Göre Karşılaştırılması

\begin{tabular}{|c|c|c|c|c|c|c|c|c|}
\hline Ölçek & $\begin{array}{c}\text { Öğrenim } \\
\text { Düzeyi }\end{array}$ & $\mathbf{n}$ & - & $\begin{array}{l}\text { Kareler } \\
\text { Toplamı }\end{array}$ & df & $\begin{array}{c}\text { Kareler } \\
\text { Ortalaması }\end{array}$ & $\mathbf{F}$ & p \\
\hline \multirow{5}{*}{ 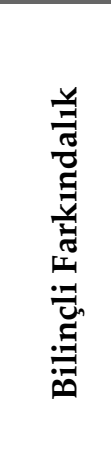 } & İlköğretim & 27 & $\begin{array}{l}\text { Gruplar } \\
\text { Arasinda }\end{array}$ & 23,52 & 4 & 5,88 & \multirow{5}{*}{11,30} & \multirow{5}{*}{0,00} \\
\hline & Lise & 46 & $\begin{array}{l}\text { Gruplar } \\
\text { İçinde }\end{array}$ & 220,60 & 424 & 0,52 & & \\
\hline & Önlisans & 51 & Toplam & 244,13 & 428 & - & & \\
\hline & Lisans & 159 & & & & & & \\
\hline & Lisansüstü & 146 & & & & & & \\
\hline \multirow{5}{*}{ 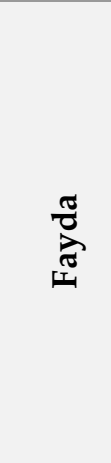 } & İlköğretim & 27 & $\begin{array}{l}\text { Gruplar } \\
\text { Arasinda }\end{array}$ & & 4 & 0,67 & \multirow{5}{*}{0,98} & \multirow{5}{*}{0,41} \\
\hline & Lise & 46 & $\begin{array}{c}\text { Gruplar } \\
\text { İçinde }\end{array}$ & & 424 & 0,68 & & \\
\hline & Önlisans & 51 & Toplam & & 428 & - & & \\
\hline & Lisans & 159 & & & & & & \\
\hline & Lisansüstü & 146 & & & & & & \\
\hline \multirow{5}{*}{ 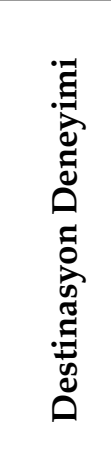 } & İlköğretim & 27 & $\begin{array}{l}\text { Gruplar } \\
\text { Arasinda }\end{array}$ & & 4 & 1,24 & \multirow{5}{*}{1,06} & \multirow{5}{*}{0,37} \\
\hline & Lise & 46 & $\begin{array}{c}\text { Gruplar } \\
\text { İçinde }\end{array}$ & & 424 & 1,16 & & \\
\hline & Önlisans & 51 & Toplam & & 428 & - & & \\
\hline & Lisans & 159 & & & & & & \\
\hline & Lisansüstü & 146 & & & & & & \\
\hline
\end{tabular}

Yukarıdaki analizlerin sonuçlarına göre yapılan Scheffe testi sonucunda (Tablo 11.), İlköğretimLisansüstü $(p=0,00)$, Lise-Lisansüstü $(p=0,00)$, Önlisans-Lisansüstü $(p=0,00)$ ve Lisans-Lisansüstü $(\mathrm{p}=0,01)$ grupları arasında anlamlı farklılık bulunmaktadır. Bu sonuçlara göre, Tablo 12.'de bakıldığında Lisansüstü eğitim almış turistlerin bilinçli farkındalık düzeyleri diğer tüm gruplar ile anlamlı farklılığa sahiptir. Bilinçli farkındalık düzeyi, bireylerin etrafında gelişen olayların farkında olması, meraklı ve dikkatli bir yaşam felsefesi benimsemesi sonucunda kazanılan bir düşünce yapısı olması sebebiyle, öğrenim hayatı boyunca araştıran ve merak eden bireyler olduğu düşünülen lisansüstü öğrenim gören bireylerde yüksek çıkmıştır. 
Tablo 6. Scheffe Testi Sonucu Öğrenim Düzeyleri Arasındaki İlişki

\begin{tabular}{|c|c|c|c|c|}
\hline Ölçek & Öğrenim Durumu & $\begin{array}{l}\text { Karşılaştırılan Öğrenim } \\
\text { Durumu }\end{array}$ & SS & $\mathrm{p}$ \\
\hline \multirow{20}{*}{$\begin{array}{l}\text { Bilinçli } \\
\text { Farkındalık }\end{array}$} & \multirow{4}{*}{ İlköğretim } & Lise & 0,17 & 1,00 \\
\hline & & Önlisans & 0,17 & 0,93 \\
\hline & & Lisans & 0,15 & 0,32 \\
\hline & & Lisansüstü & 0,15 & 0,00 \\
\hline & \multirow{4}{*}{ Lise } & İlköğretim & 0,17 & 1,00 \\
\hline & & Önlisans & 0,14 & 0,78 \\
\hline & & Lisans & 0,12 & 0,62 \\
\hline & & Lisansüstü & 0,12 & 0,00 \\
\hline & \multirow{4}{*}{ Önlisans } & İlköğretim & 0,17 & 0,93 \\
\hline & & Lise & 0,14 & 0,78 \\
\hline & & Lisans & 0,11 & 0,70 \\
\hline & & Lisansüstü & 0,11 & 0,00 \\
\hline & \multirow{4}{*}{ Lisans } & İlköğretim & 0,15 & 0,32 \\
\hline & & Lise & 0,12 & 0,06 \\
\hline & & Önlisans & 0,11 & 0,70 \\
\hline & & Lisansüstü & 0,08 & 0,01 \\
\hline & \multirow{4}{*}{ Lisansüstü } & İlköğretim & 0,15 & 0,00 \\
\hline & & Lise & 0,12 & 0,00 \\
\hline & & Önlisans & 0,11 & 0,00 \\
\hline & & Lisans & 0,08 & 0,01 \\
\hline
\end{tabular}

Tablo 13. Katılımcıların Bilinçli Farkındalık Puanı Ortalamalarının Yaş Aralıklarına Göre Karşılaştırılması

\begin{tabular}{|c|c|c|c|c|c|c|c|c|}
\hline Ölçek & $\begin{array}{c}\text { Yaş } \\
\text { Aralığ }\end{array}$ & $\mathrm{n}$ & - & $\begin{array}{l}\text { Kareler } \\
\text { Toplamı }\end{array}$ & df & $\begin{array}{c}\text { Kareler } \\
\text { Ortalaması }\end{array}$ & F & $\mathrm{p}$ \\
\hline \multirow{4}{*}{ 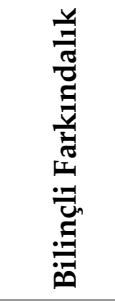 } & $\begin{array}{c}24 \text { Yaş ve } \\
\text { Altı }\end{array}$ & 91 & $\begin{array}{l}\text { Gruplar } \\
\text { Arasinda }\end{array}$ & 8,82 & 3 & 2,94 & \multirow{4}{*}{5,31} & \multirow{4}{*}{0,00} \\
\hline & 25-34 & 149 & $\begin{array}{c}\text { Gruplar } \\
\text { İçinde }\end{array}$ & 235,302 & 425 & 0,55 & & \\
\hline & 35-44 & 121 & Toplam & 244,130 & 426 & - & & \\
\hline & $\begin{array}{c}45 \text { Yaş ve } \\
\text { Üstü }\end{array}$ & 68 & & & & & & \\
\hline \multirow{4}{*}{ 胥 } & $\begin{array}{c}24 \text { Yaş ve } \\
\text { Altı }\end{array}$ & 91 & $\begin{array}{l}\text { Gruplar } \\
\text { Arasinda }\end{array}$ & 3,25 & 3 & 1,08 & \multirow{4}{*}{1,59} & \multirow{4}{*}{0,19} \\
\hline & $25-34$ & 149 & $\begin{array}{c}\text { Gruplar } \\
\text { İçinde }\end{array}$ & 288,98 & 425 & 0,68 & & \\
\hline & $35-44$ & 121 & Toplam & 292,23 & 426 & - & & \\
\hline & $\begin{array}{c}45 \text { Yaş ve } \\
\text { Üstü }\end{array}$ & 68 & & & & & & \\
\hline \multirow{4}{*}{ 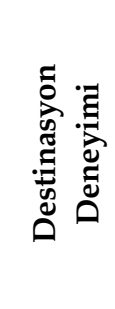 } & $\begin{array}{c}24 \text { Yaş ve } \\
\text { Altı }\end{array}$ & 91 & $\begin{array}{l}\text { Gruplar } \\
\text { Arasinda }\end{array}$ & 9,05 & 3 & 3,01 & \multirow{4}{*}{2,62} & \multirow{4}{*}{0,05} \\
\hline & 25-34 & 149 & $\begin{array}{c}\text { Gruplar } \\
\text { İçinde }\end{array}$ & 489,16 & 425 & 1,51 & & \\
\hline & 35-44 & 121 & Toplam & 498,22 & 426 & - & & \\
\hline & $\begin{array}{c}45 \text { Yaş ve } \\
\text { Üstü }\end{array}$ & 68 & & & & & & \\
\hline
\end{tabular}


Hipotez 5: Bilinçli farkındalık düzeyi, yaş gruplarına göre anlaml farklllık göstermektedir. Dutt ve Ninov'un (2015) araştırmasında, bilinçli farkındalık düzeyi ile katılımcıların yaşları arasında istatistiksel olarak anlamlı farklılık bulunamamıştır. Bu araştırma için elde edilen verilere uygulanan ANOVA testi sonucunda ise bilinçli farkındalık düzeyi ile yaş grupları arasında anlamlı farklılık bulunmaktadır ve hipotez kabul edilmiştir $(p=0,00)$. Fayda ve destinasyon deneyimi ölçeklerine bakıldığında ise anlamlı farklılık görülmemektedir. Konuya ilişkin veriler Tablo 13.'de görülmektedir.

Yukarıdaki analizlerin sonuçlarına göre yapılan Scheffe testi sonucunda (Tablo 14.), 24 yaş ve altı - 25-34 yaş aralığı, 24 yaş ve altı - 35-44 yaş aralığı grupları arasında anlamlı farklılık bulunmaktadır. Çalışmanın katılımcıların yaş aralığına ait bulguları incelendiğinde, 24 yaş ve altı katılımcıların bilinçli farkındalık düzeylerinin 25-34 yaş aralığı ve 35-44 yaş aralığında yer alan katılımcılara göre daha yüksek olduğu görülmektedir. Dolayısıyla 24 yaş ve altı katılımcıların diğer yaş aralıklarında bulunan katılımcılara göre bilinçli farkındalık düzeyleri yüksektir.

Tablo 7. Scheffe Testi Sonucu Yaş Aralıkları Arasındaki İlişki

\begin{tabular}{|c|c|c|c|c|}
\hline Ölçek & Yaş Aralı̆̆ & Karşılaştırılan Yaş Aralığı & SS & $\mathrm{p}$ \\
\hline \multirow{12}{*}{$\begin{array}{l}\text { Bilinçli } \\
\text { Farkındalık }\end{array}$} & \multirow{3}{*}{24 Yaş ve Altı } & $25-34$ & 0,09 & 0,00 \\
\hline & & $35-44$ & 0,12 & 0,01 \\
\hline & & 45 Yaş ve Üstü & 0,11 & 0,20 \\
\hline & \multirow{3}{*}{$25-34$} & 24 Yaş ve Altı & 0,09 & 0,00 \\
\hline & & $35-44$ & 0,98 & 0,99 \\
\hline & & 45 Yaş ve Üstü & 0,10 & 0,79 \\
\hline & \multirow{3}{*}{$35-44$} & 24 Yaş ve Altı & 0,10 & 0,01 \\
\hline & & $25-34$ & 0,09 & 0,99 \\
\hline & & 45 Yaş ve Üstü & 0,10 & 0,86 \\
\hline & \multirow{3}{*}{45 Yaş ve Üstü } & 24 Yaş ve Altı & 0,11 & 0,20 \\
\hline & & $25-34$ & 0,11 & 0,79 \\
\hline & & $35-44$ & 0,10 & 0,86 \\
\hline
\end{tabular}

\section{TARTIŞMA, SONUÇ ve ÖNERİLER}

Zengin bir turizm çeşitliliğine sahip olan Türkiye, sınırları içerisinde kurulmuş olan sayısız uygarlıktan kalan somut ve somut olmayan kültürel mirasların yanı sıra insanlık tarihinde önemli olan birçok kültürel varlığa ve alana sahiptir. Çatalhöyük, insanların bir arada yaşadığ ve şehir özellikleri taşıyan Dünya' daki ilk yaşam alanlarından biridir. Tarihsel öneminin yanında oldukça önemli bir turizm hazinesidir. Bilinçli farkındalık düzeyi yüksek bireylerin ziyaret ettikleri alanları daha iyi değerlendirdikleri ve bu alanlar ile ilgili görüşlerini doğru ve net bir şekilde belirttikleri önceki çalışmalarda (Moscardo, 1996; Winkle ve Backman, 2012; Chen vd., 2014; Dutt, 2016) ortaya konmuştur. Bu sebeple bu denli önemli bir turistik alanı ziyaret eden turistlerin bilinçli farkındalık düzeylerinin ölçümü büyük önem taşımaktadır. Ayrıca bilinçli farkındalık felsefesinin turizm alanında uygulanabilirliği de görülmüştür. Bu ölçümler sonucunda, Çatalhöyük'ü ziyaret eden turistlerin bilinçli farkındalık düzeylerinin yüksek olduğu görülmektedir $(5 / 3,85)$. Ayrıca Çatalhöyük'ü ziyaret eden turistlerin demografik özellikleri de belirlenmiştir. Bu sonuçlara göre her yaştan turistin Çatalhöyük Neolitik Kenti'ni ziyaret ettiği görülmektedir. Gençlerin büyük kısmının bireysel olarak veya arkadaş grupları ile bu alanı ziyaret ettiği tespit edilmiştir. Özellikle 50 yaş ve üstü katılımcıların ise rehberli turları tercih 
ettiği gözlemlenmiştir. Ayrıca alana ziyarete gelen birçok katılımcı alan hakkında olan bilgilendirici yazıları yetersiz bulmuştur.

Çatalhöyük'ü ziyaret eden turistler, seyahatlerini faydalı bulmamışlardır. T-Testi ve ANOVA testi sonuçlarına bakıldığında, Fayda ölçeğinde anlamlı bir farklılık görülmemektedir. Fayda ölçeğinde turistlere yöneltilen sorulara göz atıldığında eğlenmedikleri, alan ile ilgili bilgilerinin artmadığı, yeni şeyler öğrenmedikleri, ziyaretlerinden keyif almadıkları gibi sonuçlara ulaşılmıştır. Bu durumun, önemi yukarıda belirtilen Çatalhöyük ile ilgili çok olumsuz bir durum olduğu düşünülmektedir. Önemli bir kültür varlığının yeteri kadar ziyaretçi çekememesinin sebebi olarak da görebileceğimiz bu durum, bilinçli farkındalık felsefesine yönelik çalışmalar yapılarak düzetilebileceği düşünülmektedir çünkü bilinçli farkındalık düzeyi yüksek bireylerin görüşleri doğrultusunda yapılacak değişiklikler ve uygulanacak stratejiler veya bilinçli farkındalık düzeyi yüksek bireylerin Çatalhöyük hakkındaki görüşleri doğrultusunda yapılabilecek değişiklikler önem arz etmektedir. Çatalhöyük'te çalışan personelin bilinçli farkındalık eğitimleri alması ve kendilerini bu konuda geliştirmeleri, alanı ziyaret eden turistlerin beklentilerine cevap verilmesi konusunda önem teşkil etmektedir. Ayrıca Frauman ve Norman'a göre (2004) bilinçli farkındalık uygulamalarının yapıldığı alanlarda turistlerin tatmin düzeylerinin ve bilgi düzeylerinin arttığı gözlemlenmiştir.

Destinasyon turizmin beş temel yapısından biridir (Backer, 2008: 60). Bu sebeple Çatalhöyük'ü ziyaret eden turistlere destinasyon ile ilgili sorular yöneltilmiştir. Destinasyon Deneyimi ölçeğinde yer alan sorulara göz atıldığında, T-Testi ve ANOVA testi sonuçlarına göre Çatalhöyük'ü ziyaret eden turistlerin tekrar ziyaret eğiliminde olmadığı sonucuna ulaşılmıştır. Ayrıca çevrelerindeki ve ailelerindeki bireylere Çatalhöyük'ü tavsiye etmeyi düşünmemektedirler. Bölgeye özgü yöresel ürünleri (anket uygulaması sırasında edinilen kişisel gözlemler doğrultusunda Çatalhöyük'te bölgeye özgü yöresel ürüne rastlanılmamıştır) keşfetme şansı bulamadığı gözlemlenmiştir. Konya yöresine ve Çatalhöyük özeli düşünülerek yöresel ürünlerin pazarlanması sağlanmalıdır. Çatalhöyük ile özdeşleşen duvar resimleri ve heykellerin benzerlerinin üretilerek o bölgede satılması bu durumun önüne geçilmesini sağlayabilir. Türkiye'nin birçok turistik bölgesinde olduğu gibi kalitesiz turistik eşyaların değil, gerçekten Çatalhöyük'ün önemini ve değerini gösteren, bölgeyi özel hissettirebilecek ürünlerin satışlarının yapılması gerektiği düşünülmektedir.

Hem Fayda hem de Destinasyon Deneyimi ölçeklerinde bulunan çevre koşulları ile ilgili olarak ise her iki ölçekte de anlamlı farklılığın görülmemesi, Çatalhöyük'te çevre koşulları ile ilgili ciddi sorunların var olduğunu gösterdiği düşünülmektedir. Tüm bu sonuçlar değerlendirildiğinde, insanlık tarihinde büyük bir önemi olan Çatalhöyük'ü ziyarete gelen turistlerin hayal kırıklı̆̆ yaşamış olmasının kaçınılmaz olduğu görülmektedir. Bu sebeple, bilinçli farkındalık felsefesinin turizm hareketliliğinin en başından en sonuna kadar uygulanması gerektiği düşünülmektedir. Turistlerin çoğunlukla şikayetçi oldukları nokta ise Çatalhöyük'e giden yolun düzensiz ve yorucu olmasıdır. Özellikle kişisel araçlarıyla alana gelen ziyaretçiler yolun zor ve karmaşık olduğu görüşünü bildirmişlerdir. Bu konuda Çatalhöyük'e giden yolun direkt olarak, karmaşık olmayan bir biçimde yeniden düzenlenmesinin bu konu hakkında oluşan şikayetlere büyük ölçüde faydalı olabileceği düşünülmektedir.

Özellikle bilinçli farkındalık felsefesinin uygulamaya konulduğu alanlar incelenerek, turistlerin ziyaretlerinden memnun ve tatminkâr olarak ayrılmalarının sağlanması ve yeni yapılacak planlamalar doğrultusunda tanıtımların daha etkin bir biçimde yapılmasının gerektiği önerilmektedir. Konu ile ilgili görev yapan tüm personelin bilinçli farkındalık felsefesine yönelik eğitimler almasının da gerektiği düşünülmektedir. Dünya çapında üne sahip olan bu alanda bireysel ziyaretçiler için en azından sürekli çalışan kokartlı bir rehber istihdam edilmelidir. 
Çünkü birçok bireysel ziyaretçi Çatalhöyük'ü tam anlamıyla öğrenemeden, bilgilenemeden ziyaretlerini sonlandırmaktadır.

Bu çalışmada Çatalhöyük Neolitik Kenti ile ilgili bilgilere yer verilmiştir. Başka bir kültürel miras alanında veya başka bir tarih aralığında aynı alanda veri toplanması durumunda elde edilecek bulgular farklılık gösterebilir. Bilinçli farkındalık felsefesinin Türkiye'de ilk kez UNESCO'nun kültürel miras alanı olarak ilan ettiği bir alanda yapılması diğer turistik alanlarda yapılamayacağı anlamı taşımamalıdır. Turizm sezonunun tüm yıla yayılabilmesi için kültür turizminin öneminin büyük olduğu düşünülmektedir. Bilinçli farkındalık felsefesinin diğer turistik alanlarda uygulanması sonucunda birçok kıymetli kültürel mirasa sahip olan Türkiye'nin özellikle tanıtım ve sürdürülebilirlik konusunda yaşadığı sıkıntıları kısmen giderip daha çok turiste ev sahipliği yapacağı düşünülmektedir.

\section{KAYNAKÇA}

Alidina, S. (2019). Mindfulness for dummies, London: John Wiley \& Sons.

Backer, E. (2008). VFR Travellers-visiting the destination or visiting the hosts?, Asian Journal of Tourism And Hospitality Research, 2 (1), 60-70.

Balcı, A. (2004). Sosyal bilimlerde araştırma: yöntem teknik ve ilkeler, Ankara: Pegem Yayıncılık

Beitel, M., Ferrer, E., and Cecero, J. J. (2005). Psychological mindedness and awareness of self and others. Journal of Clinical Psychology, 61 (6), 739-750.

Bülbül, H. (2003). Rekabet üstünlüğ̈̈ sağlamada ürün ve süreç yenliği: bilişim teknolojileri uygulamasl, (Yayınlanmamış Doktora Tezi). Selçuk Üniversitesi, Konya.

Chen, L., Scott N., and Benckendorff P. (2014). Mindful tourist experiences: A Buddhist perspective, Annals of Tourism Research, 64, 1-12.

Çokluk, Ö., Şekercioğlu, G., and Büyüköztürk, Ş. (2012). Sosyal bilimler için çok değişkenli istatistik SPSS ve LISREL uygulamaları, Ankara: Pegem Akademi Yayınları.

Dutt, C., and Ninov I. (2016). Tourists' experiences of mindfulness in Dubai, United Arab Emirates (UAE), Journal of Travel \& Tourism Marketing, 33 (8), 1195-1212.

Eisenberg, N., Fabes, R. A., Murphy, B., Karbon, M., Smith, M., and Maszk, P. (1996). The relations of children's dispositional empathy-related responding to their emotionality, regulation, and social functioning. Developmental Psychology, 32 (2), 195-209.

Frauman E., and Norman W. (2004). special issue: sustainable places managing visitors via 'mindful' information services: one approach in addressing sustainability, Journal of Park and Recreation Administration, 21 (4), 87-104.

Ghaderi, Z., and Som, A. P. (2013, February). Tourism crisis management: the mindful learning from tourism crises. International Conference on Tourism Development, Penang, Malaysia.

Good, D. J., Lyddy, C. J., Glomb, T. M., Bono, J. E., Brown, K. W., Duffy, M. K., and Lazar, S. W. (2016). Contemplating mindfulness at work: An integrative review. Journal of Management, 42 (1), 114-142.

Gravetter, F. J., and Wallnau, L. B. (2013). Statistics for the Behavioral Sciences (9e Editie), London: Thomson Wadsworth Publishing.

Grossman, P. (2010). Mindfulness for psychologists: paying kind attention to the perceptible, Mindfulness, 1 (1), 87-97. 
Hayes, S., Orsillo S., and Roemer L. (2010). Changes in proposed mechanisms of action during an acceptance-based behavior therapy for generalized anxiety disorder, Behavior Research and Therapy, 48 (3), 238-245.

http://www.dosim.gov.tr/muze-istatistikleri adresinden edinilmiştir.

Kağıtçıbaşı, Ç. (2004). Yeni İnsan ve İnsanlar (10. Basım), İstanbul: Evrim Yayınevi.

Kara, E. (2016). Üniversite öğrencilerinin depresyon düzeylerinin bağlanma stilleri ve bilinçli farkındalık ile ilişkisi: öz kontrolün aracılık rolü, (Yayımlanmamış Yüksek Lisans Tezi), Anadolu Üniversitesi: Eskişehir.

Ling, T. P., Noor, S. and Mustafa H. (2015). Promoting interpretation through the concept of mindfulness: the case of selected heritage sites in Malaysia. Advances in Environmental Biology, (9) 3, 69-71.

Laurie J., and Blandford, A. (2016). making time for mindfulness, International Journal Medical Informatics, 96, 38-50.

Loureiro, S. M. C., Breazeale, M., and Radic, A. (2019b). Happiness with Rural Experience: Exploring the Role of Tourist Mindfulness as A Moderator. Journal of Vacation Marketing, 25(3), 279-300.

Manfredo, M. J., Tarrant M., and Driver B.L. (1996). measuring leisure motivation: a metaanalysis of the recreation experience preference scales, Journal of Leisure Research, 28 (3), 188-213.

Moscardo, G. and Pearce, P. L. (1986). Visitor Centre Sand Environmental Interpretation: An Exploration of the Relationships among Visitor Enjoyment, Understanding and Mindfulness. Journal of Environmental Psychology, 6 (2), 89-108.

Moscardo, G. (1996). Mindful visitors: heritage and tourism. Annals of Tourism Research, 23 (2), 376-397.

Moscardo, G. (2009). Understanding Tourist Experience Through Mindfulness Theory, Handbook of Tourist Behavior: Theory \& Practice, USA: Taylor \& Francis Group.

Mellaart, J. (2003). Çatalhöyük: Anadolu'da Bir Neolitik Kent, İstanbul: Yapı Kredi Yayınları.

Newcombe, B. C., and Weaver, A. D. (2016). Mindfulness, cognitive distraction, and sexual wellbeing in women. The Canadian Journal of Human Sexuality, 25 (2), 99-108.

Noor, S., Rasoolimanesh, M., Jaafaar, M., and Ganesan V. (2015). What influences visitor mindfulness at world heritage sites?. Tourism, Culture \& Comminication, 14, 139-150

Prentice, R., Guerin, S., and McGugan, S. (1998). Visitor learning at a heritage attraction: a case study of discovery as a media product. Tourism Management, 19 (1), 5-23.

Schermelleh, E. K., Moosbrugger, H., and Müller, H. (2003). evaluating the fit of structural equation models: tests of significance and descriptive goodnessof-fit measures, Methods of Psychological Research Online, 8 (2): 23-74.

Schmidt, K. (2007) Göbekli Tepe-En Eski Tapınağı Yapanlar, İstanbul: Arkeoloji ve Sanat Yayınevi.

Sharma, Subhash (1996). Appilied multivarite techniques, New York: John Wiley \& Sons Inc.

Sparks, B. (2007). Planning a wine tourism vacation? factors that help to predict tourist behavioral intentions, Tourism Management, 28, 1180-1192.

Stankov, U., Filimonau, V., and Vujicic M.D. (2020). A mindful shift: an opportunity for mindfulness-driven tourism in a post-pandemic world. Tourism Geographies, 22 (3), 703-712. 
Steele, M. (2008). Leading high reliability schools: the effects of organizational mindfulness on collective efficacy, (Yayımlanmamış Doktora Tezi), The University of Texas: Texas

Tan, P. L., Noor, S.M., Rasoolimanesh, S.M., and Mustafa, H. (2020). Communication and visitor factors contributing towards heritage visitors' mindfulness. Journal of Heritage Tourism, 15 (1), 2743.

Taylor, L. and Norman, W. (2019). The influence of mindfulness during the travel anticipation phase. Tourism Recreation Research, 44 (1), 76-90.

Yaylalı, M. K. (2010). Post Processual Süreç Sonrası Arkeoloji ve Kültürel Miras (Çatalhöyük Örneği), (Yayımlanmamış Yüksek Lisans Tezi), Hacettepe Üniversitesi: Ankara.

Yazıcıoğlu, Y., and Erdoğan, S. (2004). SPSS Uygulamalı Bilimsel Araştırma Yöntemleri, Ankara: Detay Yayıncilı.

Winkle, C., and Backman K. (2012). Examining visitor mindfulness at a cultural event, Journal of Heritage Tourism, 6 (1): 29-43. 